\title{
A Review of Wagner's Law and Income Elasticity of the Government Expenditures in Iran (1985-2018)
}

\author{
Reza Najarzadeh ${ }^{1}$, Elham Khorasani ${ }^{2}$ \\ ${ }^{1}$ Associate Professor and Chair, Tarbiat Modares University, Tehran, Iran, najarzar@modares.ac.ir, Corresponding Author \\ ${ }^{2}$ Ph.D. Student in Economics, Tehran University, Tehran, Iran, Elham_khorasani69@yahoo.com
}

ABSTRACT: Wagner's Law holds that the relative size of public sector increases with the growth of per capita income. The aim of this study is to investigate the validity of Wagner's Law in Iran. We test the Wagner's Law by incorporating a vector Autoregression model (VAR) and vector error correction model (VECM) for the Iranian economy using 1985-2018 health and education data. The results of the estimates show that this law holds in Iran. The elasticity of government expenditures with respect to national income must be greater than one for the Wagner's law to hold. However, government spending on health and education have been less than expected. This could suggest that the state does not pay enough attention to health and education. One can conclude that health and education are not priorities of the government in allocating funds to these two sectors.

KEYWORDS: Gross Domestic Product (GDP), Wagner's Law, Government Expenditure, Vector Autoregression (VAR), Vector Error Correction Model (VECM)

\section{Introduction}

The relationship between public expenditures and gross domestic product (GDP) has been well debated in economic literature. The role of governments and the reasons for the existence of states has been studied extensively during past decades (Peacock and Wiseman 1961). In general, some economists believe in the least interference of states in economies whereas others believe that state interference is necessary to run a smooth economy. Along with such viewpoints there are factors that can explain the size and the growth of governments in different countries. A theoretical discussion of the relationship between the general size of public sector and growth domestic product is Wagner's law, according to which increased production results in increased government spending. As a result, government services, such as judiciary, education, health and infrastructure lead to economic growth. It needs to be mentioned that other theories such as the state-run development perspective of state spending, as expressed by Musgrave and Rostow, and the Baumol's theory of growth, do explain the expansion of government size, but Wagner's theory concentrates on the relationship between GDP and government spending.

For Wagner's law to hold it is necessary that the public goods provided by the government have income elasticity greater than one. In this study the existence of Wagner's Law in the Iranian economy is examined by estimating the income elasticity of government expenditures in the health and education sectors. Also, in case the Wagner's law holds we like to show how long it takes for government size (spending) to grow at the same rate as GDP.

The hypotheses we are discussing in this study are: 1) Wagner's Law holds in Iran. 2) It takes more than one year for GDP to impact government expenditures. 3) Public education and health have an income elasticity greater than one.

\section{Wagner's Law}

The relationship between government expenditures and economic growth was first examined by the German economist Adolph Wagner (1835-1917). As the result of his studies, Wagner revealed that the speed of increase in government expenditures was higher than the speed of increase in national income (Kumar et al. 2012). In other words, he showed that the income elasticity of demand for governmental 
expenditures was higher than 1 so that governmental expenditures would increase at a higher rate than national income annually (Koop and Poirier 1995: 123). Therefore, the opinion Wagner adopted is characterized as the "Law of Governmental Expenditure Increase" in the economic literature .Wagner assumes that there is a direct relationship between government expenditures and production levels. He also emphasized that the growth of the public sector is faster than the economic growth. At the same time, market inefficiencies, in particular with regard to external implications or privileged goods, require government intervention to provide an optimal supply line of goods and services by providing subsidies or direct supply. Also, Wagner states that goods offered by the public sector are of high income elasticities (Dadgar 2007).

Government expenditures are regarded as an internal variable and the direction of causality is from economic growth to such expenditures (Bird 1971: 2). This opinion, asserted as a hypothesis by Wagner, which was then named as "Wagner's Law", constituted the basis for many theoretical and empirical studies to follow.

\subsection{Various forms of Wagner's Law}

Empirically Wagner's law refers to the long-term relationship between government size (usually government spending) and income (GDP). Since there are different criteria for measuring government size, such as the ratio of government expenditure to income, per capita government expenditures and consumption expenditures, and also there are various criteria for income measurement such as income and per capita income we are faced with different empirical versions of Wagner's Law as follows:

\begin{tabular}{|c|c|c|}
\hline Peacock-Wismen (1967) & $\beta>1$ & $L n G_{t}=\alpha+\beta \operatorname{LnGDP} P_{t}+\varepsilon_{1 t}$ \\
\hline Pryor (1969) & $\beta>1$ & $\operatorname{LnGC} C_{t}=\alpha+\beta \operatorname{LnGDP} P_{t}+\varepsilon_{2 t}$ \\
\hline Gupta (1967) & $\beta>1$ & $\operatorname{Ln}(G / P)_{t}=\alpha+\beta \operatorname{Ln}(G D P / P)_{t}+\varepsilon_{3 t}$ \\
\hline Goffman (1967) & $\beta>1$ & $L n G_{t}=\alpha+\beta \operatorname{Ln}(G D P / P)_{t}+\varepsilon_{4 t}$ \\
\hline Musgrave (1969) & $\beta>0$ & $\operatorname{Ln}(G / G D P)_{t}=\alpha+\beta \operatorname{Ln}(G D P / P)_{t}+\varepsilon_{5 t}$ \\
\hline Man (1980) & $\beta>0$ & $l N(G / G D P)_{t}=\alpha+\beta L n G D P_{t}+\varepsilon_{6 t}$ \\
\hline
\end{tabular}

Where $\operatorname{LnG}_{t}: \log$ of government expenditures, $\operatorname{LnGC}_{t}$ : Log of consumption expenditure, P: population, Ln (G/P) $t$ : Log of per capita government expenditure, Ln (G/GDP) $)_{t}$ Log of the share of government expenditures from income, $\operatorname{LnGDP}_{\mathrm{t}}$ : Log of income, and $\operatorname{Ln}(\mathrm{GDP} / \mathrm{P})_{\mathrm{t}}$ : Log of per capita income. For the realization and confirmation of the Wagner hypothesis in the above models, it is necessary that the estimated coefficient $(\beta)$ be equal to the values given above.

\section{Literature review}

Hussain et al. (2010) examined the validity of Wagner's Law and the relationship between economic growth, population and exports for Pakistan. The ARDL Bounds Cointegration and ECM were used for the long and the short run equilibrium for the period of 1972-2007. With the increase in GDP, the government expenditures may or may not increase. The empirical results indicate that the Wagner's Law does hold, as economic growth is significantly and positively is correlated with government expenditures. However, population and exports also have significant and positive impact on government expenditures both in the short and the long run. The significant and negative coefficient of error correction term in ECM indicates that after a shock, the long run equilibrium will again converge towards its equilibrium at about 70.82 percent within a year. 
Srinivasan (2013) investigated the causal nexus between public expenditure and economic growth in India using Cointegration approach and Error Correction Model (ECM). The analysis was carried out for the period 1973 to 2012. The Cointegration test results confirm the existence of a long-run equilibrium relationship between public expenditure and economic growth in India. The empirical results based on ECM indicates a one-way causality run from economic growth to public expenditure in the short-run and long-run, supporting the Wagner's law of public expenditures.

Abu Eideh (2015) studied the causal relationship between public expenditure and the GDP growth in the Palestinian territories during 1994-2013. They found that there exist a two-way causal relation between public expenditures and GDP growth in Palestine.

\section{Methodology and Data}

Johansen's (1988) cointegration approach and Vector Error Correction Model (VECM) have been employed to investigate the causal relationship between public expenditures and economic growth in Iran. Before doing cointegration analysis, it is necessary to test the stationarity of the series. The Augmented Dickey-Fuller (1979) test was employed for this purpose. If the series are non-stationary in levels and stationary in differences, then there is a chance of cointegration relationship between them which reveals the long-run relationship between the series. Johansen's cointegration test has been employed to investigate the long-run relationship between the two variables. Besides, the causal relationship between Gross Domestic Product (GDP) and public expenditure was investigated by estimating the following Vector Error Correction Model (VECM) (Johansen, 1988).

$\Delta X_{t}=\sum_{i=1}^{p-1} \Gamma_{i} \Delta X_{t-i}+\prod X_{t-1}+\varepsilon_{t} ; \varepsilon_{t} \mid \Omega_{t-1} \sim \operatorname{distr}\left(0 . H_{t}\right)$

where $\Delta$ denotes the first difference operator, $\varepsilon_{\mathrm{t}}$ is a $2 \mathrm{x} 1$ vector of residuals with mean zero and timevarying covariance matrix, $\mathrm{H}_{\mathrm{t}}$. The VECM specification contains information on both the short- and the long-run adjustment to changes in $X_{t}$, via the estimated parameters $\Gamma_{\mathrm{i}}$ and $\Pi$, respectively. $X_{t}$ is a $2 \mathrm{x} 1$ vector of log-Public expenditure and log-Gross Domestic Product (GDP).

There are two likelihood ratio tests that can be employed to identify the cointegration between the two series. The variables are cointegrated if and only if a single cointegrating equation exists. The first statistic $\lambda_{\text {trace }}$ tests the number of cointegrating vectors is zero or one, and the other $\lambda_{\text {max }}$ tests whether a single cointegrating equation is sufficient or if two are required. In general, if the $r$ cointegrating vector is correct, the following test statistics can be constructed as:

$\lambda_{\text {trace }}(r)=-T \sum_{i=r+1}^{n} \ln \left(1-\widehat{\lambda_{l}}\right)$
$\lambda_{\text {max }}(r . r+1)=-T \ln \left(1-\widehat{\lambda_{r+l}}\right)$

where $\hat{\lambda}_{l}$ are the eigen values obtained from the estimate of the $\Pi$ matrix and $\mathrm{T}$ is the number of usable observations. The $\lambda_{\text {trace }}$ tests the null that there are at most $r$ cointegrating vectors, against the alternative that the number of cointegrating vectors is greater than $r$ and the $\lambda_{\max }$ tests the null that the number of cointegrating vectors is $r$, against the alternative of $r+1$. Critical values for the $\lambda_{\text {trace }}$ and $\lambda_{\text {max }}$ statistics are provided by Osterwald-Lenum (1992).

In this study, the annual time series data of the variables under consideration, namely the Gross Domestic Product without oil (GDP) and the public expenditure of Iran, have been carried out from the year 1985 to 
2018. The real Gross Domestic Product (GDP) is used as a proxy for economic growth in Iran and we represent the economic growth by using the constant value of GDP measured in Iranian money (rial). The total expenditure of the central government $(\mathrm{G})$ has been considered for public expenditure under the study, oil revenues (OIL), gross domestic product per capita without oil (GDPP), oil per capita (OILP), government spending on health (HY), and government spending on education (ED). All variables are logarithmic and therefore the estimated coefficients are elasticity measures. All necessary data for the sample period are obtained from the Central Bank of Iran.

\section{Empirical Results and Discussion}

In this study, given that per capita GDP (GDP/P) and the ratio of government expenditures to income (G/GDP) (equations (2) to (6)) do not have unit roots, they cannot be used in a VECM model. Only Wagner's model presented by Peacock Wismen (equation (1)) which does not have restriction is estimated. First, we examine the variables in terms of stationarity and then we estimate the model. We will then estimate the revenue elasticity of health and education expenditures provided by the government.

Peacock-Wismen's model states that GDP (income) is the reason for rising government spending. In this study, GDP is divided into two parts:

1. GDP without oil at the base price of 2002

2. Oil Revenues at the base price of 2002

As a result, the above example is expressed as:

$\ln G_{t}=\alpha+\beta \ln G D P_{t}+\varepsilon_{t}$

In order to estimate the revenue elasticity of government expenditure in health and education sector, we use the following equations respectively:

$$
\begin{aligned}
& E D=\alpha_{1}+\beta_{1} \ln (G D P / P)_{t}+\varepsilon_{t} \\
& H Y=\alpha_{2}+\beta_{2} \ln (G D P / P)_{t}+\varepsilon_{t}
\end{aligned}
$$

\subsection{Unit Root Test}

The Augmented Dickey-Fuller test (ADF) was employed to test the stationarity of the variables. The null hypothesis is that variables in level have unit root and therefore are nonstationary, while the opposite hypothesis means that the variables in level are stationary. The test reveals that all variables become stationary when their first differences are used and it can be concluded that they have unit roots. In other words, it can be determined that all the variables are integrated in order of one, I (1). The results of first difference ADF test of these variables are presented in Table 1.

Table 1. Dickey-Fuller test for unit roots

\begin{tabular}{|c|c|c|c|c|}
\hline Variable & ADF-statistic & t-statistic (1\%) & t-statistic (5\%) & Prob \\
\hline LG & -3.440327 & -3.421023 & -2.943927 & 0.0157 \\
\hline LGDP & -4.088576 & -3.605593 & -2.936942 & 0.0027 \\
\hline LOIL & -3.794875 & -3.621023 & -2.943427 & 0.0064 \\
\hline LGDPP & -3.952156 & -3.605136 & -2.886954 & 0.0040 \\
\hline ED & -7.192053 & -3.59669 & -2.975236 & 0.0000 \\
\hline HY & -7.730797 & -3.625606 & -2.981593 & 0.0000 \\
\hline
\end{tabular}




\subsection{Determining the Optimum Lag Length of the VAR Model}

The estimation of the Johansen's Cointegration model requires the estimation of a system of VAR equations. However, to obtain this an optimal lag length is required.

Among the various criteria used to determine an optimal lag, Akaike Information Criterion (AIC), Schwarz-Bayesian (SC), Hannan Quinn (HQ), Final Prediction Error (FPE) and the Likelihood Ratio (LR) were used. The statistical results are shown in Table 2 with lengths of $\mathrm{P}=1,2$ and 3 lags.

Table 2. VAR Lag Order Selection Criteria

\begin{tabular}{|c|c|c|c|c|c|}
\hline Lag Length & LR & FPE & AIC & SC & HQ \\
\hline 0 & NA & 0.002505 & 2.524162 & 2.660208 & 2.569937 \\
\hline 1 & 214.5944 & $2.65 \mathrm{e}-06$ & -4.330189 & -3.786004 & -4.147087 \\
\hline 2 & 21.68654 & $2.02 \mathrm{e}-06$ & -4.618832 & -3.666509 & -4.298404 \\
\hline 3 & 9.178022 & $2.43 \mathrm{e}-06$ & -4.472422 & -3.111960 & -4.014668 \\
\hline
\end{tabular}

In general, when the number of observations or sample size is less than 100, the Schwarz criterion yields better results than other criteria. According to the Schwarz criterion, the optimal lag length is 1 .

\subsection{Johansen's Cointegration Test}

Once the optimum lag is determined and the VAR model is estimated. Johansen's Cointegration Test (1998) was performed to examine the long-run relationship between public expenditure and other variables. Johansen test uses the maximum likelihood method to determine the cointegration relationship. If the variables are cointegrated, it means that they move together over time, so that short-term disturbances are corrected in the long run. The results are presented in Table 3.

Table 3. Johansen's Cointegration test

\begin{tabular}{|c|c|c|c|c|}
\hline $\begin{array}{c}\text { Hypothesized } \\
\text { No. of CE(s) }\end{array}$ & Eigen value & Trace Statistic & 0.05 Critical Value & Prob.** \\
\hline None $*(r=0)$ & 0.727643 & 54.31922 & 29.79707 & 0.0000 \\
\hline At most $1(\mathrm{r} \leq 0)$ & 0.252955 & 11.39801 & 15.49471 & 0.1882 \\
\hline At most 2 $(\mathrm{r} \geq 0)$ & 0.052345 & 1.774234 & 3.841466 & 0.1829 \\
\hline
\end{tabular}

Trace test indicates 1 cointegrating eqn(s) at the 0.05 level

* denotes rejection of the hypothesis at the 0.05 level

**MacKinnon-Haug-Michelis (1999) p-values

The Johansen's cointegration tests result reject the null hypothesis of no cointegration at the 5 percent significance level. Thus, it can be concluded that GDP, public expenditure (G) and LOIL are cointegrated or they co-move in the long run. The above results allow us to estimate the VECM model with cointegration vectors.

\subsection{Estimation of the VECM model}

This model relates the volatility of short-term variables to their long-term values and considers the shortterm dynamic response between variables. In this section, the results of estimating error correction equations are presented Table 4. 
Table 4. Vector Error Correction Estimates

\begin{tabular}{|c|c|c|c|}
\hline Variables & $\mathrm{D}(\mathrm{LG})$ & $\mathrm{D}(\mathrm{LGDP})$ & $\mathrm{D}(\mathrm{LOIL})$ \\
\hline Error Correction & 0.015686 & 0.010468 & 0.111483 \\
& $(0.02002)$ & $(0.00629)$ & $(0.025350)$ \\
& {$[0.78357]$} & {$[1.66347]$} & {$[4.39860]$} \\
\hline
\end{tabular}

$\begin{array}{ccc}\mathrm{D}(\mathrm{LG})= & 3.424176 \mathrm{LGDP}(-1) & +6.653224 \operatorname{LOIL}(-1) \\ \mathrm{se} & (0.72800) & (0.90785) \\ \mathrm{t} & {[4.70355]} & {[7.32856]}\end{array}$

The coefficients of the equation show that GDP growth will increase government spending indicating that Wagner's law holds in Iran. Also, if oil revenues increase one percent, government expenditure increase 6.65 percent.

The government expenditures elasticity with respect to GDP and oil revenues are estimated to be higher than one, and the government's response to rising oil revenues is about twice as high. This indicates that government expenditures depend on oil revenues. The t-statistic implies a significant causality running from GDP to public expenditure in the short-run.

\subsection{Response Functions}

These functions are a moving average of the VAR model and enable characterization of the dynamic interactions among variables and allow us to observe the speed of adjustment of variables in the system. Figure 1 plots the response of public expenditure to shocks in GDP and vice versa. The effect of a GDP shock on government expenditures is increasing over time. In fact, it will take about four years to have an impulse-free GDP shock on government spending.
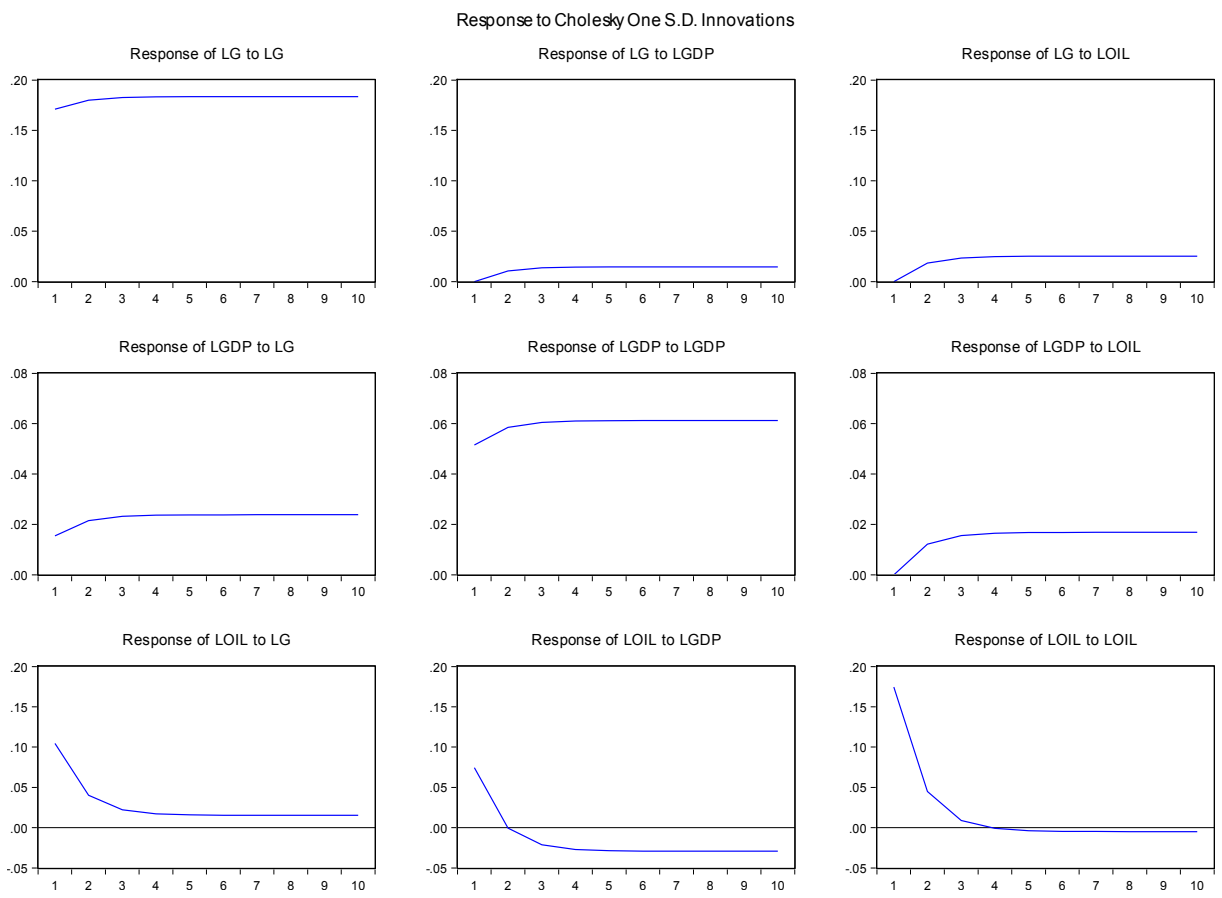

Figure 1. Response Functions 


\subsection{Estimating Income Elasticity of Government Expenditures on Health and Education}

To estimate the income elasticity of government expenditures in the two sectors of health and education we use Vector Error Correction Estimation as shown in Table 5.

Table 5. Vector Error Correction Estimates

\begin{tabular}{|c|c|c|}
\hline \multicolumn{2}{|c|}{ Variables } & LGDPP \\
\hline \multirow{2}{*}{ ED } & & 10356.40 \\
& & $(5651.14)$ \\
& Error & {$[1.83262]$} \\
\cline { 3 - 3 } HY & Correction & 3003.369 \\
& & $(240.187)$ \\
& & {$[12.5043]$} \\
\hline
\end{tabular}

From Table 5 the following estimated equations for ED and HY are obtained:

$\mathrm{ED}=\alpha_{1}+10356.40$ LGPPP

$\mathrm{HY}=\alpha_{2}+3003.369$ LGDPP

From the above equations income elasticities for health and education are calculated and presented in Table 6.

Table 6. Income Elasticities of Government Expenditures on Health and Education

\begin{tabular}{|c|c|c|}
\hline \multirow{2}{*}{ Income Elasticity } & Health & Variables \\
\cline { 2 - 3 } & 0.95 & 0.40 \\
\hline
\end{tabular}

Elasticity of government spending on health is 0.95 . If GDP grows by $1 \%$, government spending in health will increase by $0.95 \%$. Therefore, the government expenditures in the health sector are not bigger than one, but close to one. Income elasticity of government spending in the education sector is 0.40 . If GDP increases by one percent, government spending in the education sector will increase by $0.4 \%$.

\section{Conclusions and Policy Recommendations}

The purpose of this study was to investigate the causal nexus between public expenditures and economic growth in Iran using cointegration approach and error correction model. The analysis was carried out over the period 1985 to 2018. Wagner's Law explains the relationship between GDP growth and government expenditure. Wagner's Law has been expressed in different versions. In this study, we estimate the Peacack and Wismen version. Considering the positive and significant coefficient estimates we conclude that Wagner's Law holds in Iran (validity of the first hypothesis). According to the estimates, it takes four years for a GDP shock to fully affect government expenditures. Therefore, the second hypothesis that it takes more than one year for the GDP effect to be fully realized is confirmed. Income elasticities of government spending on health and education was estimated to be less than one. As a result, the third hypothesis that income elasticity of health and of education is higher than one is rejected.

With respect to oil revenues, much of the government's response depends on this variable and GDP without oil has no power to explain changes in government spending, which indicates the high contribution of oil revenues in explaining government expenditures. As a result, GDP without oil plays a very small role in adjusting government expenditure. This indicates a strong dependence of the Iranian economy on oil resources. On the other hand, the share of government spending in health and education sectors in the overall government spending is negligible. This could suggest that the government does not 
pay enough attention to health and education. One can conclude that health and education are not priorities of the government in allocating proper budget share to these sectors.

\section{References}

Abu-Eideh, O. 2015. "Causality between Public Expenditure and GDP Growth in Palestine: An Econometric Analysis of Wagner's Law." Journal of Economics and Sustainable Development, 6.

Dadgar, Yadolah. 2007. Public Economics. Qom: Mofid University Press.

Dickey, D. A. and Fuller, W. A. 1979. "Distribution of the estimates for autoregressive time series with a unit root." Journal of American Statistical Association 74(366): 427-431.

Hussain, T., Iqbal, A. \& Siddiqi, M.W. 2010. "Growth Population, Exports and Wagner's Law." International Journal of Human and Social Sciences, 5.

Im, K.S., Pesaran, H. and Shin, Y. 2003. "Testing for Unit Roots in Heterogeneous Panels." Journal of Econometrics 115(1): 53-74.

Johansen, S. 1988. "Statistical Analysis and Cointegrating Vectors." Journal of Economic Dynamics and Control 12(2-3): 231-254.

Johansen, S. and Juselius, K. 1990. "Maximum Likelihood Estimation and Inference on Co-integration with Applications for the Demand for Money." Oxford Bulletin of Economics and Statistics 52(2): 169-210.

Peacock, Alan T. Wiseman, Jack. 1961. The Growth of Public Expenditure in the United Kingdom. Princeton University Press (p. 35 - 51).

Peacock, A. T, \& Wiseman, J. 1979. "Approaches to the Analysis of Government Expenditure Growth." Public Finance Quarterly 7, PP. 3-23.

Pesaran, M. H. 2003. "A Simple Panel Unit Root Test in the Presence of Cross Section Dependence." Mimeo University of Southern California.

Phillips, P.C.B. \& Perron, P. 1988. “Testing for Unit Roots in Time Series Regressions”, Biometrika 75(2)ş 335-346.

Srinivasan, P. 2013. "Causality between Public Expenditure and Growth: The Indian Case." Journal of Economic and Management 335-347.

Souri, Ali. 2014. Econometrics, Vol. II, Farhangshenasi Publishing, Third Edition

Wagner, A. 1883. "Three Extracts on Public Finance." In R. A. Musgrave and A. T. Peacock eds 1958. Classics in the Theory of Public Finance, London: Macmillan. 